\title{
Daya Bunuh Insektisida Hayati Vermileachate dan Teh Vermikompos Terhadap Kutu Kebul (Bemisia tabaci Genn.) pada Tanaman Mint (Mentha piperita L.)
}

\section{Vermicompost Tea and Vermileachate as Natural Insecticide Against Whitefly (Bemisia tabaci Genn.) at Mint Tree (Mentha piperita $\mathbf{L}$.)}

\author{
Nathanael Wirandhi Syarief ${ }^{1 *}$, Wibowo Nugroho Jati ${ }^{1}$, Felicia Zahida ${ }^{1}$ \\ ${ }^{1}$ Fakultas Teknobiologi, Universitas Atma Jaya Yogyakarta, \\ Email: nathanaelwirandhi@gmail.com*Penulis untuk korespondensi
}

\begin{abstract}
Vermicompost tea and vermileachate are derivative liquid derivate from vermicompost which contains active substances as the insecticide. Purpose of this research is to find out the potential insecticide - of vermicompost tea and vermilachate on Bemisia tabaci Genn. from Mentha piperita L. which has toxicity of $50 \%$. The study Research used FRD (factorial randomized design) with treatment in three replications. The given cosentration are $10,20,30$ and $40 \%$ on exposture time of 6,12 , and 24 hours. The results show that Vermicompost tea with a concentration of $30 \%$ and vermileachate with a concentration of $20 \%$ give B. tabaci from Mint the toxicity of 45,82 and 46,18\%.
\end{abstract}

Keywords: Vermicompost tea, vermileachate, Bemisia tabaci, mortality, Mentha piperita

\begin{abstract}
Abstrak
Teh vermikompos dan vermileachate merupakan cairan turunan produk vermikompos yang mengandung berbagai senyawa aktif yang berperan sebagai insektisida. Penelitian ini bertujuan mengetahui daya bunuh larutan uji terhadap Bemisia tabaci Genn. dari tanaman mint (Mentha piperita $L$.) dengan konsentrasi dan waktu paparan teh vermikompos dan vermileachate yang memberikan dampak daya bunuh $\pm 50 \%$. Percobaan penelitian menggunakan RAF (rancangan acak faktorial) sebanyak tiga kali pengulangan. Konsentrasi larutan yang diberikan ialah 10, 20, 30, dan $40 \%$ dengan waktu paparan 6, 12, dan 24 jam. Simpulan yang didapatkan dari penelitian ini adalah teh vermikompos konsentrasi $30 \%$ dan vermileachate konsentrasi $20 \%$ menyebabkan daya bunuh $B$. tabaci dari tanaman mint sebesar 45,82 dan 46,18 \% .
\end{abstract}

Kata kunci : Teh vermikompos, vermileachate, Bemisia tabaci, daya bunuh, Mentha piperita

Diterima : 3 Agustus 2018, disetujui : 20 September 2018

\section{Pendahuluan}

Pestisida hayati berperan terhadap pengendalian hama terpadu (PHT) (Novizan, 2002). Pestisida hayati aman bagi lingkungan dan manusia serta tidak memberikan efek samping pada penggunaan jangka pendek dan jangka panjang (Bunders dkk., 1996). Keuntungan dari pestisida hayati ialah terdegradasi, residu cepat hilang, tidak mencemari lingkungan, aman terhadap makhluk hidup (Novizan, 2002); bahan baku murah, mudah didapat, dan sederhana (Soenandar dkk., 2010). Kerja pestisida hayati sebagai repelan dan antifedan (Novizan, 2002).

Vermikompos merupakan hasil dari proses dekomposisi senyawa organik secara aerobik nontermofilik mengunakan cacing (Singh dan Singh, 2014). Proses vermikompos diawali dengan permbuatan bedding. Bedding merupakan media pertumbuhan cacing. Bedding menggunakan campuran serat dan kotoran hewan. Serat berfungsi sebagai agen bulking (Munroe, 2004). 
Proses vermikompos dengan pemupukan awal (precomposting) meningkatkan jumlah populasi cacing selama proses vermikompos (Frederickson dkk., 1997), efektif mentransformasi hasil dekomposisi yang lebih banyak pada bahan kertas (Frederickson dkk., 2007), membantu dalam stabilisasi sampah, $\mathrm{pH}$, kelembaban, pengurangan massa sampah, serta efektif untuk menginaktivasi patogen. $\mathrm{C} / \mathrm{N}$ rasio dilaporkan lebih rendah saat menggunakan precomposting (Nair dkk., 2006).

Proses vermikompos menghasilkan cairan lindi yang disebut vermileachate sedangkan teh vermikompos merupakan cairan hasil perendaman vermikompos pada air pada waktu tertentu secara aerasi atau non-aerasi (Quaik dan Ibrahim, 2013). Teh vermikompos dibuat menggunakan prinsip aerasi (Edwards dkk., 2009; Arancon dkk., 2007).Kedua cairan dari vermikompos ini memiliki potensi sebagai insektisida hayati (Edwards dkk., 2009; Quaik dan Ibrahim, 2013; Sharma dkk., 2009).

B. tabaci merupakan hama tanaman yang menyebabkan penurunan fotosintesis akibat daun tertutup honeydew (Malumphy, 2017). Serangga ini juga merupakan hewan pembawa virus germinivirus penyebab klorotik dan penggulungan pada daun (Markham dkk., 1994). B. tabaci banyak ditemukan pada tanaman mint di Greenhouse Boutique Hotel dimungkinkan karena posisi hotel yang bersebelahan dengan pasar. Keberadaan B. tabaci pada tanaman mint juga ditemukan di Orange dan Suwannee (negara bagian Florida) (McKenzie dkk., 2009), Israel (Kementrian Pertanian dan Pembangunan Desa Israel, 1999), dan Florida (McKenzie dan Osborne, 2017).

Permasalahan hama di Greenhouse Boutique Hotel ini serta potensi teh vermikompos dan vermileachate sebagai pestisida hayati mendasari penelitian ini. Teh vermikompos dan vermileachate dipaparkan pada hama dalam kondisi laboratorium untuk melihat kemampuan daya bunuhnya (persen mortalitas) pada faktor konsentrasi dan waktu paparan. Penilitian ini sebagai bagian awal kajian untuk penelitian serupa kedepannya dan penanganan hama di di Greenhouse Boutique Hotel.

\section{Metode Penelitian}

\section{Persiapan Larutan Uji}

Vermileachate (cairan lindi vermikompos) dan vermikompos (kompos cacing/kascing) diambil dari vermikompos kotoran sapi Proses pembuatan vermikompos kotoran sapi selama 30 hari (modifikasi Edwards dan Arancon, 2004). Larutan uji yang dipersiapkan yaitu vermileachate, teh vermikompos, dan kontrol positif. Vermileachate diambil dari saluran pengeluaran pada wadah bawah di ember vermikompos. Larutan vermileachate merupakan larutan dengan konsentrasi $100 \%$. Kontrol positif merupakan pestisida hayati komersial (merk X) (ekstrak tanaman) sebagai pembanding. Pembuatan teh vermikompos (konsentrasi $40 \%$ ) dengan prinsip aerasi selama 12 jam (modifikasi Edwards dkk., 2009). Larutan uji dibuat variasi konsentrasi sesuai rancangan percobaan. Larutan uji ditambahkan surfaktan (tween 20) dengan konsentrasi 0,001 \% (Putra dkk., 2011).

\section{Pengujian Daya Bunuh Insektisida (metode leaf disc)}

Daun mint dan Bemisisa tabaci diambil dari greenhouse yang telah dipersiapkan sebelum penelitian. Tanaman mint merupakan jenis $M$. Piperita dan ditanam secara hidroponik. $B$. tabaci merupakan hama liar dan ditangkap menggunakan aspirator. Jenis tanaman dan hama divalidasi menggunakan kecocokan morfologi dengan data yang diambil dari internet.

Daun mint (daun ke 3-4 dari pucuk) diambil, dibilas dan dikeringkan dengan tissu steril. Daun dicelupkan ke dalam larutan uji sesuai perlakuan selama 20 detik. Daun dikeringanginkan selama 20 detik dan diletakkan di atas petri berisi agar padat $(2 \%$ ) dengan posisi adaxial. $B$. tabacidewasa diambil dengan aspirator dan dimasukkan ke dalam plastik klip yang telah dilubangi (10-20 serangga tiap perlakuan)(Sabtharishi dan Naven, 2017).

Serangga dipelihara dalam ruangan sengan suhu $27 \pm 2{ }^{\circ} \mathrm{C}$, fotoperiode $12 \mathrm{jam}$, dan kelembaban 60-70 \% (dalam ruangan ber-AC dan pengaturan caha menggunakan lampu LED). Mortalitas serangga diamati pada jam ke-6, 12, dan 24. Sirkulasi udara diatur dengan aerator. Pengulangan pengujian dilakukan sebanyak 3 
kali dan dihitung persen mortalitasnya (Sabtharishi dan Naven, 2017). Data mortalitas dikoreksi dengan formula Abbott (Abbott, 1925). Analisis beda perlakuan mengunakan uji ANAVA dengan tingkat kepercayaan 90\%. Beda nyata perlakuan dengan duncan's multiple range test (DMRT). Perhitungan dan analisis menggunakan program SPSS versi 15.

\section{Karakterisasi Kandungan Larutan Uji}

Karakterisasi kandungan larutan uji terdiri dari tiga uji meliputi uji fenol $\left(\mathrm{FeCl}_{3}\right)($ Ahluwalia dan Dhingra, 2000; Putri dan Hidajati, 2015), uji kandungan unsur hara, dan deteksi sederhana Bacillus thuringiensis dengan metode Ohba dan Aizawa (Saadoun dkk., 2001).Uji kandungan unsur hara meliputi uji kandungan $\mathrm{C}$ (Walkey \& Black), N (kjeldahl), P (spektrofotometer UV-vis: $\lambda=889 \mathrm{~nm}$ ), $\mathrm{K}$ (flamefotometer: $\lambda=766$ ), $\mathrm{Fe}$ (AAS: $\lambda=372 \mathrm{~nm}$ ), $\mathrm{S}$ (spektrofotometer UV-vis: $\lambda=625 \mathrm{~nm}$ ), dan Mg (ICP: $\lambda=279,08 \mathrm{~nm}$ ). Uji unsur hara sebagai strandarisasi kandungan unsur hara sampel penelitian yang merupakan cairan ekstrak vermikompos.

\section{Hasil dan Pembahasan}

Pengujian fenol menunjukkan hasil negatif (Gambar 1) karena tidak membentuk warna warna biru/ merah/ hijau/ ungu (Ahluwalia dan Dhingra, 2000). Hasil negatif pada uji ini bukan berarti sampel benar-benar negatif mengandung fenol. Perlu adanya indentifikasi lebih lanjut menggunakan metode lainnya (Ahluwilia dan Dhingra 2000).

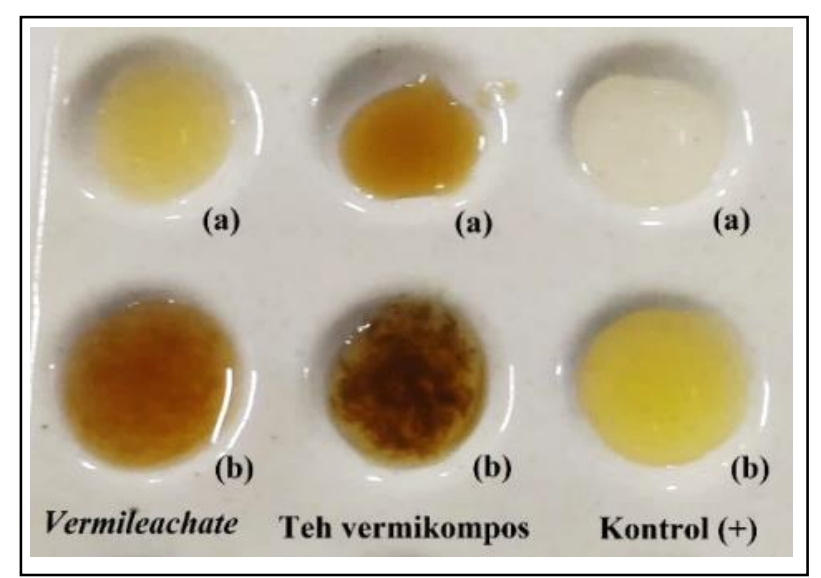

Gambar 1. Uji fenol kualitatif larutan insektisida Keterangan: (a) sebelum penambahan $\mathrm{FeCl}_{3}$; (b) sesudah penambahan $\mathrm{FeCl}_{3}$

Senyawa fenol pada vermikompos dihasilkan oleh sistem pencernaan cacing (Vinken dkk., 2005). Fenol oksidase endogenus terdeteksi di L.rubellus yang mengaktifkan pnitrofenol yang toxik (Park dkk., 1996). Fenolik terlarut di vermikompos dapat diserap oleh tanaman menyebabkan jaringan tanaman yang berasa tidak enak bagi serangga. Senyawa fenolik memberi dampak menekan laju reproduksi dan kelangsungan hidup hama (Edwards dkk., 2010; Edwards dkk., 2009). Senyawa fenolik merupakan antifedan (Khoul, 2008).

Ditemukan 2 koloni dugaan Bacillus thuringiensis masing-masing satu pada teh vermikompos dan vermileachate. Pengujian biokimia dan pengecatan Gram menunjukkan bahwa isolat bakteri pada teh vermikompos merupakan bakteri Arthrobacter citreus sedangkan isolat bakteri pada vermileachateialah Streptomyces rochei.

A. citreus memiliki kemampuan untuk mendegradasi residu pestisida kimia (Datta dkk., 2000). S. rochei bermanfaat mengatasi serangan Fusarium oxysporum (Kanini dkk., 2013), Rhizoctonia solani (Zamoum dkk., 2017), Botryosphaeria dothidea (Zhang dkk., 2016), Alternaria alternata, dan Drechslera halodes (Hussein dkk., 2014). Kajian mengenai potensi $A$. citreus dan $S$. rochei sebagai insektisida belum 
pernah dilakukan. Teh vermikompos ditemukan bakteri Actinomyces, Nitrosovibrio, Nitrosospira, Acinetobacter, dan Sphingobacterium (Fritz dkk., 2012). Belum terdapat publikasi data mengenai bakteri yang terdapat pada vermileachate.

Larutan uji dilakukan analisis kandungan unsur hara (hasil Tabel 1). Uji kandungan unsur hara dilakukan untuk melihat kualitas larutan uji dikarenakan sampel turunan ekstrak larutan dari vermikompos. Umumnya teh vermikompos mengandung unsur hara lebih banyak dibandingkah vermileachate (Zarei dkk., 2018; Hargreaves dkk., 2008). Kualitas unsur hara teh vermikompos dan vermileachate didasarkan pada kualitas vermikompos (Pant dkk., 2012; Zaeri dkk., 2018).

Tabel 1. Kandungan unsur hara larutan uji

\begin{tabular}{llll}
\hline \hline \multicolumn{1}{c}{ Parameter } & \multicolumn{1}{c}{ Kontrol positif } & \multicolumn{1}{c}{ Teh Vermikompos } & Vermileachate \\
\hline \hline Karbon Organik & 22860 & 13310 & 16930 \\
\hline Nitrogen $(\mathrm{N})(\mathrm{ppm})$ & 150 & 130 & 160 \\
\hline Fosfat $(\mathrm{P})(\mathrm{ppm})$ & 47,745 & 80,01 & 21,24 \\
\hline Kalium $(\mathrm{K})(\mathrm{ppm})$ & 105 & 1157 & 2258 \\
\hline Besi (Fe) (ppm) & 0,2974 & 1,9 & 1,2934 \\
\hline Magnesium (Mg) $(\mathrm{ppm})$ & 3,96 & 5,04 & 3,48 \\
\hline Sulfida (S) (ppm) & $<0,0043$ & $<0,0043$ & $<0,0043$ \\
\hline pH & 7,56 & 6,99 & 8 \\
\hline \hline
\end{tabular}

Berdasarkan grafik daya bunuh $B$. tabaci (Gambar 2) teh vermikompos dan vermileachatemenyebabkan mortalitas (daya bunuh) pada B. tabaci dari tanaman mint. Daya bunuh $B$. tabaci terhadap konsentrasi dan waktu paparan berbanding lurus. Daya bunuh tertinggi ditunjukkan pada konsentrasi larutan uji tertinggi $2 \%$ untuk kontrol positif serta $40 \%$ untuk vermilachate dan teh vermikompos dengan waktu paparan 24 jam.

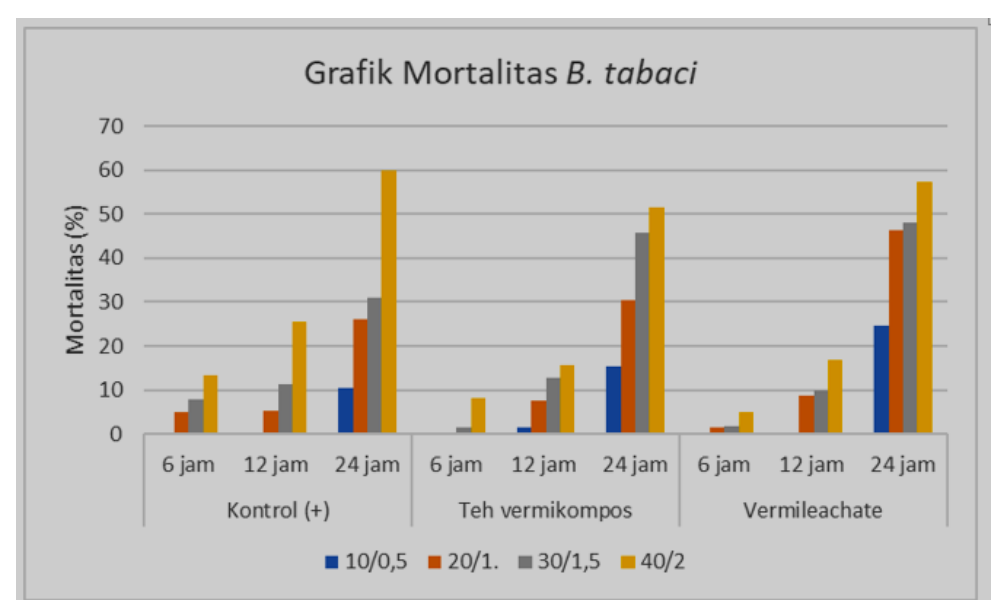

Gambar 2. Daya bunuh B. tabaciterhadap larutan insektisida Konsentrasi: 10, 20, 30, dan $40 \%$ (teh vermikompos/ vermileachate)/ 0,$5 ; 1 ; 1,5$; dan $2 \%$ (kontrol positif)

Daya bunuh efektif (yang menyebabkan kematian 50\% serangga) ditunjukkan oleh waktu paparan 24 jam dengan mortalitas kontrol positif $60 \%$ (konsentrasi $2 \%$ ), teh vermikompos $51,64 \%$ (konsentrasi $40 \%$ ), dan vermileachate $57,45 \%$ (konsentrasi $40 \%$ ).
Vermileachate mengandung enzim protease, urease, fosfatase, dan amilase (Zambare dkk., 2008; Shivsubramanian dan Ganeshkumar, 2004). Enzim protease pada perlakuan vermileachate berperan besar menyebabkan matinya serangga dengan cara merusak jaringan 
protein pada tubuh serangga yang berujung pada kematian serangga. Vermikompos dilaporkan mengandung enzim kitinase yang merombak kitin pada serangga, akan tetapi tingkat kemampuannya belum dipublikasi.

Hasil analisis ANAVA daya bunuh antara teh vermikompos dan vermileachate menunjukan bahwa perlakuan konsentrasi dan waktu menunjukkan rerata yang berbeda sedangkan antarperlakuan teh vermikompos dan vermileachate tidak menunjukkan beda perlakuan. Menurut Quaik dan Ibrahim (2013), tidak adanya beda perlakuandikarenakan kedua larutan ini merupakan turunan estrak dari vermikompos yang sama. Perlakuan dilakukan analisi lanjut DMRT untuk melihat beda nyata. Perlakuan waktu 6, 12, dan 24, masing-masing menunjukkan beda nyata sedangkan perlakuan konsentrasi beda nyata ditunjukkan pada konsentrasi 10, (20 dan 30) serta $40 \%$. Antara konsentrasi 20 dan $30 \%$ tidak menunjukkan beda nyata.

Hasil analisis menunjukkan bahwa larutan insektisida efektif pada waktu paparan 24 jam. Perlakuan 24 jam (teh vermikompos, vermileachate, dan kontrol positif) dilakukan analisis DMRT untuk mengetahui konsentrasi efektif serta efektifitas terhadap kontrol positif (pestisida hayati komersial). Hasil menunjukkan bahwa mortalitas efektif sebagai insektisida $( \pm 50 \%)$ teh vermikompos pada konsentrasi $30 \%$ dan vermileachate $20 \%$. Hasil penetitian sebelumnya pada penelitian Edwards dkk. (2009), pada serangga ulat tanduk tembakau pada tanaman timun dan kumbang timun bergaris pada tanaman tomat menggunakan konsentrasi 10 dan $20 \%$. Konsentrasi $20 \%$ menunjukkan effektifitas paling optimum dengan waktu paparan 9 hari pada serangga ulat tanduk tembakau dan 5 hari pada kumbang timun bergaris.

Teh vermikompos $(30 \%)$ dan vermileahate $(20 \%)$ dengan kontrol positif (2\%) menunjukkan persen mortalitas yang sama.Efektifitas teh vermikompos ataupun vermileachate masih belum bersaing dengan kontrol positif. Konsentrasi paparan teh vermikompos dan vermileachate (30 dan $20 \%$ ) masih lebih tinggi dibandingkan kontrol positif $(2 \%)$.

\section{Simpulan}

Teh vermikompos dan vermileachate berpotensi sebagai insektisida pada Bemisia tabaci dari tanaman mint. Daya bunuh efektif ditunjukkan oleh teh vermikompos konsentrasi $30 \%$ dan vermileachate konsentrasi $20 \%$ menyebabkan mortalitas B. tabaci sebesar 45,82 dan $46,18 \%$ dengan waktu paparan 24 jam.

\section{Ucapan Terimakasih}

Peneliti mengucapkan terima kasih kepada Greenhouse Boutique Hotel atas dukungan dan kesempatan yang diberikan selama penelitian.

\section{Daftar Pustaka}

Abbott, W. S. 1925. A method of computing the effectiveness of an insecticide. J Econ Entomol, 18: 265-267.

Ahluwalia, V. K. dan Dhingra, S. 2000. Comprehensive Practical Organic Chemistry: Qualitative Analysis. Universities Press, India. Hal. 22 - 23.

Arancon, N. Q., Edwards, C. A., Dick, R., dan Dick, L. 2007. Vermicompost tea production and plant growth impacts. BioCycle, 48 (11): 51-52.

Bunders, J., Haverkort, B., dan Hiemstra, W. 1996. Biotechnoogy: Building on Farmers' Knowledge Maxmillan Education Ltd, London. Hal 52 - 54

Datta, J., Maiti, A. K., Modak, D. P., Chakrabartty, P. K., Bhattacharyya, P., dan Ray, P. K. 2000. Metabolism of $\gamma$-hexachlorocyclohexane by Arthrobacter citreus strain BI-100: Identification of metabolites. J. Gen, Appl. Microbiol., 46: 59-67.

Edwards C. A., Arancon N. Q., Bennett M. V., Askar A. Keeney G., dan Little B. 2010. Suppression of green peach aphid (Myzus persicae) (Sulz.), citrus mealybug (Planococcus citri) (Risso), and two spotted spider mite (Tetranychus urticae) (Koch.) attacks on tomatoes and cucumbers by aqueous extracts from vermicomposts. Crop Prot, 29:80-93.

Edwards, C. A., Arancoan, N. Q., Vasko-Bennett, M., Askar, A., dan Keeney, G. 2009. Effect of aqueous extracts from vermicomposts on attacks by cucumber beetles (Acalymna vittatum) (Fabr.) on cucumbers and tobacco hornworm (Manduca sexta) (L.) on tomatoes. Pedobiologia, 53 (2): 141 - 148. 
Edwards, C. A. dan Arancon, N. Q. 2004. The use of earthworms in the break down of organic wastes to produce vermicomposts and animal feed protein. Dalam: Edwards, C. A. Earthworm Ecology. CRC Press, Boca Raton, Hal 345 - 438.

Frederickson, J., Butt, K. R., Morris, R. M., Daniels, C. 1997. Combining vermiculture with traditional green waste composting systems. Soil Biolology and Biochemistry, 29 (3-4): 725 - 730.

Frederickson, J., Howell, G., dan Hobson, A. M. 2007. Effect of pre-composting and vermicomposting on compost characteristics. European Journal of Soil Biology, 43: 320 - 326.

Fritz, J. I., Franke-Whittle, I. H., Haindi, S., Insam, H., dan Braun, R. 2012. Microbiological community analysis of vermicompost tea and its influence on the growth of vegetables and cereals. Canadian Journal of Microbiology, 58 (7): 836847.

Hargreaves, J., Adl, M. S., Warman, P. R., dan Rupasinghe, H. P. V. 2008. The effects of organic amendments on mineral element uptake and fruit quality of raspberries. Plant Soil, 308 213-226.

Hussein, A. A. E., Alhasan, R. E. M., Abdelwahab, S. A., dan Siddig, M. A. 2014. Isolation and identification of Streptomyces rochei strain active against phytopathogenic fungi. British Microbiology Research Journal, 4 (10): 10571068 .

Kanini, G. S., Katsifas, E. A., Savvides, A. L., dan Karagouni, A. D. 2013. Streptomyces rochei ACTA1551, an indigenous Greek isolate studied as a potential biocontrol agent against Fusarium oxysporum f.sp. lycopersici. BioMed Research International, 2013: 1-10.

Kementrian Pertanian dan Pembangunan Desa Israel. 1999. Conforidor.

http://www.hadbara.moag.gov.il/hadbara/englis $\mathrm{h} /$ search/Applications_No.asp?mone $=80 \&$ prodI $\mathrm{d}=1134$. 27 Januari 2018.

Khoul, O. 2008. Phytochemical and insect control: An antifeedant approach. Crit. Rev. Plant Sci., 27: $1-24$.

Malumphy, C. 2017. Tobacco, Sweet potato or Silver leaf whiteflyBemisia tabaci. Department for Environment Food and Rural Affairs, Unites Kingdom. Hal. 2, 3, 5.

Markham, P. G., Bedford, I. D., Liu, S., dan Pinner, M. S. 1994. The Transmission of Geminiviruses by Bemisia tabaci. Pesticide Sci., 42:123-128.

McKenzie, C. L. dan Osborne, L. S. 2017. Bemisia tabaci MED (Q biotype) (Hemiptera: Aleyrodidae) in Florida is on the move to residential landscapes and may impact open-field agriculture. Florida Entomologist, 100 (2): 481 - 484.
McKenzie, C. L., Hodges, G., Osborne, L. S., Byrne, F. J., dan Shatters, R. G. 2009. Distribution of Bemisia tabaci (Hemiptera: aleyrodidae) biotypes in Florida-investigating the $\mathrm{Q}$ invasion. Journal Of Economic Entomology, 102 (2): 670 - 676.

Munroe, G. 2004. Manual of On-Farm Vermicomposting and Vermiculture. Organic Agriculture centre of Canada (OACC), Dalhousie Univercity, Nova Scotia. Hal. 10 - 12.

Nair, J., Sekiozoic, V., dan Anda, M. 2006. Effect of precomposting on vermicomposting of kitchen waste. Bioresource Technology, 97: 2091 2095 .

Novizan. 2002. Membuat dan Memanfaatkan Pestisida Ramah Lingkungan. PT AgroMedia Pustaka, Depok. Hal. 18 - 19, 22 - 24.

Pant, A. P., Radovich, T. J. K., Hue, N. V., dan Paull, R. E. 2012. Biochemical properties of compost tea associated with compost quality and effects on pak choi growth. Sci Hortic, 148: 138-146.

Pant, A., Radovich, T. J. K., Hue, N. V., dan Arancon, N. Q 2011. Effects of vermicompost tea (aqueous extract) on pak choi yield, quality, and on soil biological properties. Compost Science and Utilization, 19 (4): 279-292.

Park, S. R., Cho, E. J., Yu, K. H., Kim, Y. S., Suh, J. J., Chang, C. S. 1996. Endogenous phenoloxidase from an earthworm Lumbricus rubellus. Tongmul Hakoehi, 39:36-46.

Putra, C. D. P., Fachriyah, E., dan Kusrini, D. 2011. Isolasi, identifikasi dan uji toksisitas senyawa steroid dalam ekstrak kloroform daun ketapang (Terminalia catappa Linn). Jurnal Kimia Sains dan Aplikasi, 14 (1): 4-7.

Putri, A. A. S. dan Hidajati, N. 2015. Uji aktivitas antioksidan senyawa fenolik ekstrak metanol kulit batang tumbuhan nyiri batu (Xylocarpus muloccensis). UNESA Journal of Chemistry, 4 (1): 1 - 6 .

Quaik, S. dan Ibrahim, M. H. 2013. A review on potential of vermicomposting derived liquids in agricultural use. International Journal of Scientific and Research Publications, 3 (3): 1 -

Saadoun, I., Al-Momani, F., Obeidat, M., Meqdam, M., dan Elbeticha, A. 2001. Assesment of toxic potential of logal Jordanian Bacillus thuringiensis strains on Drosophila melanogaster and Culex sp. (Diptera). Journal of Applied Microbiology, 90 (6): 866-872.

Sabtharishi, S. dan Naven, N,C. 2017. Protocol exchage: Bioassay for monitoring insecticide toxicity in Bemisia tabaci populations. https://www.nature.com/protocolexchange/prot 
Syarief $d k k$,

ocols/5517\#/author-information. 29 Desember 2017.

Sharma, S., Kumar, A., Singh, A. P., dan Vasudevan, P. 2009. Earthworms and vermicomposting- a review. Dynamic Soil, Dynamic Plant, 3 (2): 1 12.

Shivsubramanian, K. dan Ganeshkumar, M. 2004. Influence of vermiwash on biological

Vinken, R., Schaeffer, A. dan Ji, R. 2005. Abiotic association of soil-borne monomeric phenols with humic acids. Org. Geochem., 36: 583-593.

Zambare, V. P., Padul, M. V., Yadav, A. A., dan Shete, T.B. 2008. Vermiwash: biochemical and microbiological approach as eco friendly soil conditioner. ARPN Journal of Agricultural and Biological Science, 3 (4): 1 - 5.

Zamoum, M., Goudjal, Y., Sabaou, N., Mathieu, F., dan Zitouni, A. 2017. Development of formulations based on Streptomyces rochei strain PTL2 spores for biocontrol of Rhizoctonia solani damping-off of tomato seedlings. Journal Biocontrol Science and Technology, 27 (6): 723-738. productivity of marigold. Madras Agricultural Journal, 91: 221 - 225.

Singh, M. K. dan Singh, P. 2014. Handbook on Vermicomposting. Anchor Academic Publishing, Hamburg. Hal. 2, 31.

Soenandar, M., Aeni, M. N., dan Raharjo, A. 2010. Petunjuk Praktis Membuat Pestisida Organik. Agromedia Pustaka, Jakarta. Hal 37.

Zarei, M., Abadi, V. A. J. M., dan Moridi, A. 2018. Comparison of vermiwash and vermicompost tea properties produced from different organic beds under greenhouse conditions. International Journal of Recycling of Organic Waste in Agriculture, 7: 25-32.

Zhang, Q., Yong, D., Zhang, Y., Shi, X., Li, B., Li, G., Liang, W., dan Wang, C. 2016. Streptomyces rochei A-1 induces resistance and defenserelated responses against Botryosphaeria dothidea in apple fruit during storage. Postharvest Biology and Technology, 115: 3037. 